\title{
IMPACT OF JAPANESE LESSON STUDY \\ IN TEACHERS' CONTENT KNOWLEDGE AS A NEW MODEL FOR TEACHERS' DEVELOPMENT IN SAUDI ARABIA
}

\author{
Maged Almadi ${ }^{i}$ \\ PhD Student, \\ School of Education, \\ University of Glasgow, \\ United Kingdom
}

\begin{abstract}
:
School-based professional development is an appropriate way of tailoring professional development both to the needs of the individual teacher and of the school. Lesson Study (LS) is one of the models of school-based professional development. It is a professional learning method that is based on collaboration amongst teachers, in order to improve their professional development and students' outcomes. The Saudi Ministry of Education, since 2015, started a pilot project that utilized the LS in certain Saudi schools in different regions to meet professional learning needs. The purpose of this study is to understand the impact of LS as a model adopted for the professional development of teachers by Primary Schools in Riyadh region in Saudi Arabia. The study utilised a quantitative research method based on an online survey to collect data from four selected elementary schools in the Riyadh region. SPSS software was used to analyse the questionnaire responses. Overall, the results for this study identified that LS serves as an effective tool for teachers' professional development and that most of the teachers have positive perception towards using the LS model as a tool for improving teachers' content knowledge.
\end{abstract}

Keywords: lesson study, school-based, professional development, Saudi Arabia

\section{Introduction}

Started over a century ago, the origins of Lesson Study (hereafter, LS) as a model of school-based professional development is traceable to Japan (Murata, 2011). The model, essentially, is a professional learning method that is based on collaboration amongst teachers, in order to improve their professional learning and student outcomes (Wood and Cajkler, 2017). LS has since become one of the most popular models used for

\footnotetext{
i Correspondence: email msalmadi@hotmail.com, m.almadi.1@research.gla.ac.uk
} 
professional learning for teachers globally (Warwick, et al., 2016). The model is currently implemented in a number of countries including: Singapore, China, Hong Kong, Indonesia, UK, Sweden, Norway, Spain, and the US based on its envisaged benefits. This paper is part of a bigger project that seeks to explore perceptions of teachers and principals of selected schools in the Kingdom of Saudi Arabia (hereafter, KSA) about using LS as a model of professional development. Specifically, this paper focuses on how the use of LS as a school-based professional development strategy for teachers in the KSA helps in developing their content knowledge (hereafter, $\mathrm{CK}$ ).

\section{Literature Review}

Similar to many school-based teaching models, LS accommodates the needs of teachers and helps to improve their teaching practices focusing on the development of their professional teaching and learning communities (Engelbrecht, Ankiewicz \& Swardt, 2007; Gettly, 2002; Stoll et al., 2006). LS is also seen as an appropriate way of tailoring professional development both to the needs of the individual teacher and of the school. Further, LS has been identified as a useful tool for developing teachers through learning in action, since it enables teachers to be better educators through continuous professional development (Loucks-Horsley et al., 1998). According to Fernandez and Chokshi (2002), the LS model is systematic and more focused on the student learning experience and classroom needs with the sole aim to aid teachers to improve their work practices. LS also assists teachers to identify learning challenges that are related to specified area of action, like a particular skill or field of subject content because the model is based on a critical review of learning students (Wood and Cajkler, 2017). The distinctiveness of the LS model lies on its concentration on the learning (observing pupils learning), as opposed to the performance of teachers; and on the collective work of the teachers, instead of the performance of an individual teacher (Stigler and Hiebert, 1999; Yoshida, 2002; Stepanek, et al., 2007).

In the KSA, the Saudi government has shown leadership by implementing an LS strategy, providing financial support for the project, and preparing the requisite infrastructure for the project to succeed.

Figure 1 below illustrates a typical LS model consisting of a cycle of at least three 'research lessons' that are jointly planned, taught/observed and analysed. 


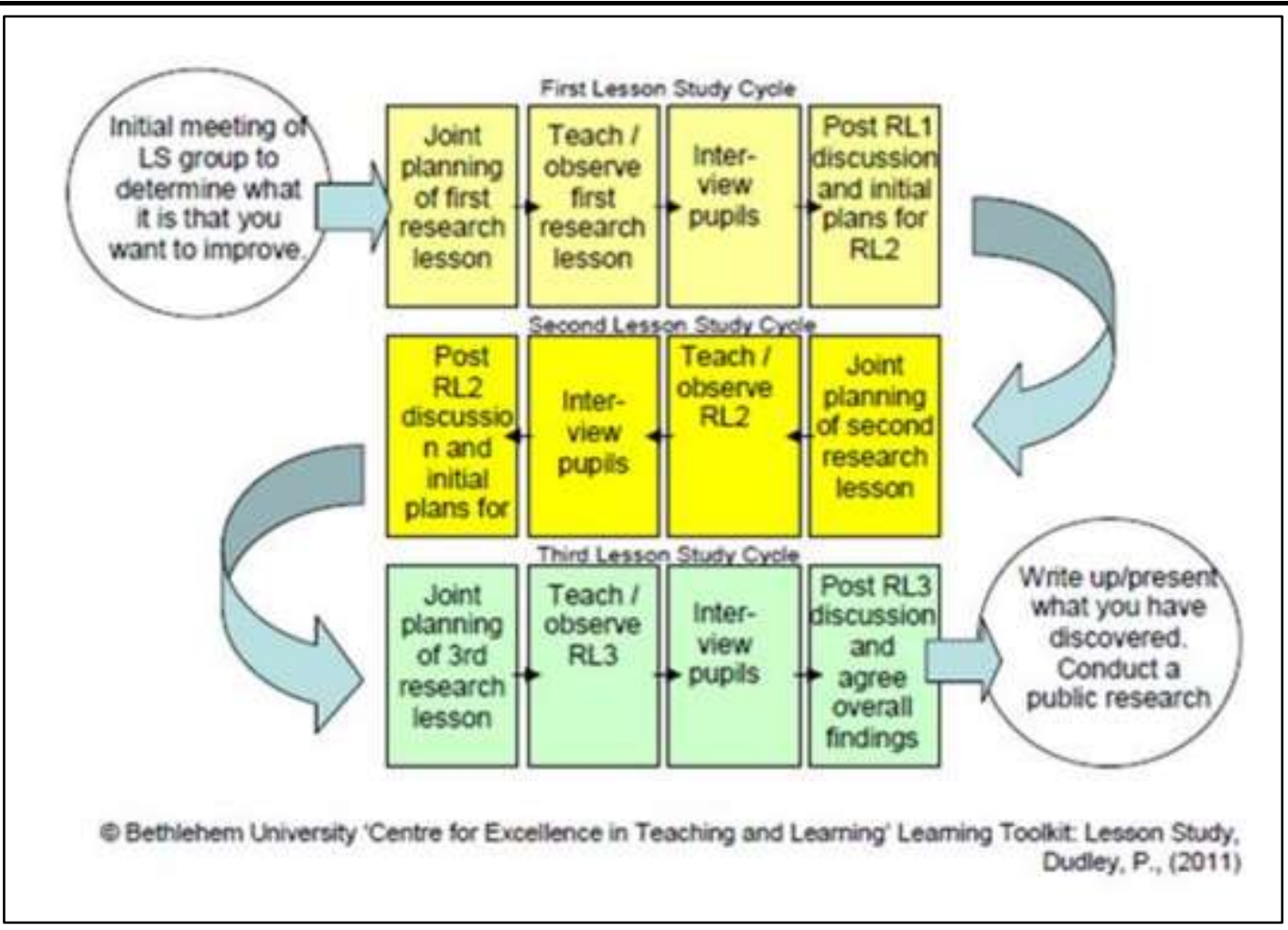

Figure 1: LS cycle in the UK. Dudley (2014, p. 5)

\section{Materials and Methods}

The study used a quantitative method approach based on a questionnaire. The questionnaire was developed by the researcher to a sample size of 50 participants consisting of teachers and principals of primary schools who have used and are still using the LS model. All the research participants were provided with an information pack about the study and their written and signed consent obtained before their participation. The eligibility criteria was basically being a teacher or principals of the selected primary schools who was willing to participate in the project from start to finish.

\section{Results and Discussion}

The questionnaire sought to measure teachers' perceptions regarding the use of LS in developing their $\mathrm{CK}$, of which the results is presented in table 1 below.

Table 1: The use of LS in developing their content knowledge

\begin{tabular}{|c|l|c|c|c|c|}
\hline $\begin{array}{c}\text { Item No in } \\
\text { the Ques }\end{array}$ & \multicolumn{1}{|c|}{ Statements } & Mean & SD & Attitude & Rank \\
\hline 9 & $\begin{array}{l}\text { Sufficient knowledge of the basic concepts that } \\
\text { students are expected to learn in the subject I'm } \\
\text { teaching }\end{array}$ & 4.36 & $\mathbf{8 9 8}$ & SA & $\mathbf{1}$ \\
\hline 10 & $\begin{array}{l}\text { Ensuring a deeper understanding of the scientific } \\
\text { content related to my field of specialization }\end{array}$ & $\mathbf{4 . 3 2}$ & $\mathbf{. 9 5 7}$ & SA & $\mathbf{3}$ \\
\hline
\end{tabular}




\begin{tabular}{|c|l|c|c|c|c|}
\hline \hline 11 & $\begin{array}{l}\text { Perceiving the scientific links between my field of } \\
\text { specialization and other fields }\end{array}$ & 4.12 & .895 & A & 5 \\
\hline 12 & $\begin{array}{l}\text { Being prepared for discussing any scientific or } \\
\text { perceptual aspects related to my field of } \\
\text { specialization }\end{array}$ & 4.30 & .931 & SA & 4 \\
\hline 13 & $\begin{array}{l}\text { Ability to link the subject with the student's real } \\
\text { life }\end{array}$ & 4.34 & .961 & SA & 2 \\
\hline
\end{tabular}

As shown in table 1 above, the overall teachers' perceptions regarding the use of the LS model in developing their CK is high with the mean (4.28) and SD (0.790). This indicates that most of the teachers have positive perception toward using the LS model. Further, the responses from the research participants appeared to suggest a ranking in their perceptions of how the use of LS helps in developing their CK. For instance, the question of teachers' "Sufficient knowledge of the basic concepts that students are expected to learn in the subject I'm teaching", was ranked top most in the teachers' perceptions regarding the use of LS in developing their CK with mean (4.36) and SD (0.898). On the other hand, the question of teachers', "Perceiving the scientific links between my field of specialization and other fields", was ranked bottom with mean (4.12) and SD (0.895). In between these two ends were questions about their: "Ability to link the subject with the student's real life" (ranked 2 ${ }^{\text {nd }}$ ); "Ensuring a deeper understanding of the scientific content related to my field of specialization" (ranked 3r); and "Being prepared for discussing any scientific or perceptual aspects related to my field of specialization" (ranked $4^{\text {th }}$ ). Although the questionnaire did not provide an opportunity for the participants to offer reasons for their ranking, nonetheless, the outcome is somehow reflective of their individual experiences of the use of LS in developing their CK.

Overall, the evidence in the results of the questionnaire revealed that most participants scored the scale items as "strongly agree". This means that, there was a general positive attitude towards the adoption and use of the LS model in developing their CK. This research outcome is consistent with outcomes from a good number of previous studies across the world. Meyer (2006), for instance, indicated an improvement in the CK of the research participant through their involvement in the LS process. Further, studies have demonstrated participants' satisfaction with the impact of LS on their CK (Dudley, 2013; Sitton, 2006); the effectiveness of its structured and powerful nature in developing the CK of teachers and improving their practices (Björk and Pettersson, 2015; Lewis and Perry, 2014; Hunter and Back, 2011; Fernandez, 2009); its resourcefulness in improving the understanding of teaching materials (Suh and Seshaiyer, 2015; Mitcheltree, 2006); as well as the promotion and improvement in teacher competence in CK (Acquah et al., 2013). 


\section{Recommendations}

It is argued in the literature that the use of the LS model as a professional development tool is directly related to its efficacy in meaningful ways in enhancing the CK of teachers (Elmore \& Burney, 2000; Guskey \& Sparks, 2002; Dudly, 2014). Yet, there is still room for improvement in its adoption and usage depending on the context. In this study, the following recommendations are made for both policy and practice in the KSA going forward:

- Increment in budgetary allocation and the provision of adequate instructional materials to all schools for the implementation of the LS model.

- Development of a comprehensive and orderly expansion strategy for in the implementation of LS in Saudi Arabia.

- Collation between implementing schools and the authorities under the Saudi MoE.

- Putting in place culturally appropriate systems that can help in evaluating the effectiveness of the LS model as a professional development model.

- Promoting further research in the use of the LS model across schools throughout the KSA.

\section{Conclusion}

This study contributes to the literature on the implementation of LS in countries other than Japan. Given that Saudi Arabia is different from Japan in terms of geopolitical as well as socio-cultural terms, the findings of this study will help support the implementation of LS in cultures similar to that of the KSA.

\section{Acknowledgements}

This is paper is part of a larger project for my PhD in Education at the University of Glasgow. I would like to acknowledge the input of my supervisors through their feedback on my draft chapters. In the spirit of full disclosure, I would also like to express my gratitude to my sponsor, the Saudi Ministry of Education. Finally, my special appreciation goes to the teachers and principals of schools who volunteered to participate in this research.

\section{References}

Acquah, S., Adzifome, N. S., \& Afful-Broni, A. (2013). Ensuring quality education in Ghana: Experiences of basic school mathematics and science teachers. Journal of Education and Practice, 4(25), 41-50.

Björk, M. \& Pettersson-Berggren, M. (2015). Teachers developing teaching: A comparative study on critical features for pupils' perception of the number line. International Journal for Lesson and Learning Studies, 4(1), 383-400. 
Dudley, P. (2013). Teacher learning in Lesson Study: What interaction-level discourse analysis revealed about how teachers utilised imagination, tacit knowledge of teaching and fresh evidence of pupils learning, to develop practice knowledge and so enhance their pupils' learning. Teaching and teacher education, 34, 107-121.

Dudley, P. (Ed.). (2014). Lesson Study: Professional learning for our time. London: Routledge. Elmore, R., \& Burney, D. (2000). Staff Development and Instructional Improvement. In D. Burney (Ed.) (pp. 1-39): Consortium for Policy Research in Education. The Albert Shanker Institute.

Engelbrecht, W., Ankiewicz, P. \& de Swardt, E. (2007). An industry sponsored school focused model for continuing professional development of technology teachers. South African Journal of Education, 27, 579-595.

Fernandez, C. \& Chokshi, S. (2002). A practical guide to translating lesson study for a U.S. setting. The Phi Delta Kappan, 84(2), 128-134.

Fernandez, C. (2009). Lesson study: A means for elementary teachers to develop the knowledge of mathematics needed for reform-minded teaching? Mathematical Thinking and Learning, 7(4), 265-289.

Gettly, M. F. (2002). Rigtingwysers vir die indiensopleiding van onderwysers. DEdproefskrif. Johannesburg: Randse Afrikaanse Universiteit.

Guskey, T. R., \& Sparks, D. (2002). Linking Professional Development to Improvements in Student Learning. Thousand Oaks. Corwin Press, Inc.

Hunter, J. \& Back, J. (2011). Facilitating Sustainable Professional Development through Lesson Study. Mathematics Teacher Education and Development, 13(1), 94-114.

Lewis, C. \& Perry, R. (2014). Lesson Study with Mathematical Resources: A Sustainable Model for Locally-Led Teacher Professional Learning. Mathematics Teacher Education and Development, 16(1).

Loucks-Horsley, S., Hewson, P., Love, N., \& Stiles, K. (1998). Designing professional development for teachers of science and mathematics. Thousand Oaks: Corwin Press.

Meyer, R. D. (2006). Lesson study: the effects on teachers and students in urban middle schools (Doctoral dissertation).

Murata, A. (2011). Introduction: Conceptual overview of lesson study. In L. C. Hart, A. Alston, \& A. Murata (Eds.), Lesson study research and practice in mathematics education: Learning together (pp. 1-12). London: Springer.

Sitton, P. A. (2006). The effectiveness of lesson study as a professional development model for K5 th grade teachers. Unpublished doctoral dissertation, Capella University.

Stepanek, J., Appel, G., Leong, M., Mangan, M., \& Mitchell, M. (2007). Leading lesson study: A practical guide for teachers and facilitators. Thousand Oaks, CA: Corwin Press.

Stigler, J. M., \& Hiebert, J. (1999). The teaching gap: Best ideas from the world's teachers for improving education in the classroom. New York: Free press.

Stoll, L., Bolam, R., McMahon, A., Wallace, M. \& Thomas, S. (2006). Professional Learning communities: A review of the literature. Journal of Educational Change, 7, 221-258. 
Suh, J. \& Seshaiyer, P. (2015). Examining teachers' understanding of the mathematical learning progression through vertical articulation during lesson study. Journal of Mathematics Teacher Education, 18(3), 207-229.

Warwick, P., Vrikki, M., Vermunt, J. D., Mercer, N., \& van Halem, N. (2016). Connecting observations of student and teacher learning: an examination of dialogic processes in Lesson Study discussions in mathematics. ZDM, 48(4), 555-569.

Wood, P. \& Cajkler, W. (2017). Lesson study: A collaborative approach to scholarship for teaching and learning in higher education, Journal of Further and Higher Education, DOI: 10.1080/0309877X.2016.1261093.

Yoshida, M. (2002). Overview of lesson study in Japan. Paper presented at lesson study conference, New Orleans. Retrieved 14 July 2017, from Research for Better Schools: http://www.rbs.org/Special-Topics/Lesson-Study/Lesson-Study-Conference2002/Overview-ofLesson-Study-in-Japan/206/printstyle--true. 

will be applied to their work. Under the terms of this license, no permission is required from the author(s) or publisher for members of the community to copy, distribute, transmit or adapt the article content, providing a proper, prominent and unambiguous attribution to the authors in a manner that makes clear that the materials are being reused under permission of a Creative Commons License. Views, opinions and conclusions expressed in this research article are views, opinions and conclusions of the author(s). Open Access Publishing Group and European Journal of Education Studies shall not be responsible or answerable for any loss, damage or liability caused in relation to/arising out of conflicts of interest, copyright violations and inappropriate or inaccurate use of any kind content related or integrated into the research work. All the published works are meeting the Open Access Publishing requirements and can be freely accessed, shared, modified, distributed and used in educational, commercial and non-commercial purposes under a Creative Commons Attribution 4.0 International License (CC BY 4.0). 